Arch. Tierz., Dummerstorf 48 (2005) 3, 290-298

University of Veterinary and Pharmaceutical Sciences Brno, Czech Republic

VLADIMÍR VEČEREK, PAVEL SUCHÝ, EVA STRAKOVÁ, FRANTIŠEK VITULA and MARKÉTA MIKUNDOVÁ

\title{
Variation in the chemical composition of muscles in young pheasants during their growth*
}

\begin{abstract}
The paper reports on the changes in the chemical composition of breast and thigh muscles in intensively fed chickens of common pheasant, discussing the results obtained from the perspective of the production of highquality pheasant meat. Young pheasants were fed for 90 days. Unlike breast muscles, thigh muscles showed a significant $(\mathrm{P} \leq 0.05)$ decrease in water content between Day 50 and Day 90 (falling from 757.20 to $728.61 \mathrm{~g} / \mathrm{kg}$ ) which was associated with increasing dry matter content in muscles (from 242.80 to $271.39 \mathrm{~g} / \mathrm{kg}$ ). From a dietetic point of view, one positive finding is that both breast and thigh muscles from young pheasants aged 40 90 days contained low levels of fat, ranging from $6.12 \mathrm{~g} / \mathrm{kg}$ to $8.33 \mathrm{~g} / \mathrm{kg}$, and from $20.36 \mathrm{~g} / \mathrm{kg}$ to $51.37 \mathrm{~g} / \mathrm{kg}$, respectively. However, at the end of the monitored period (i.e. between Day 70 and Day 90) fat content in muscles significantly increased $(\mathrm{P} \leq 0.01)$. Differences between average levels of ash (minerals) in breast muscles during the monitored period were not statistically significant. The average levels of ash in thigh muscles decreased statistically very significantly $(\mathrm{P} \leq 0.01)$ on Day $50(11.75 \mathrm{~g} / \mathrm{kg})$. In breast muscles a statistically significant decrease $(\mathrm{P} \leq 0.05)$ was detected on Day $90(11.67 \mathrm{~g} / \mathrm{kg})$. The above-mentioned changes in the chemical composition of muscles in young pheasants may arise due to qualitative age-related changes such as decreasing proteosynthesis and enhanced fat biosynthesis in muscles. This conclusion is supported by profound changes in the parameters of chemical composition related to muscle dry matter which are presented in this paper.
\end{abstract}

Key Words: pheasant, common pheasant, feeding, growth, chemical composition of muscles

\section{Zusammenfassung}

Titel der Arbeit: Unterschiede in der chemischen Zusammensetzung der Muskulatur junger Fasanenhühner im Wachstumsverlauf

Untersucht wird die chemische Zusammensetzung der Brust- und Oberschenkelmuskulatur bei intensiver Fütterung des Kupferfasans, mit dem Ziel der Produktion eines hochwertigen Fasanenwildbretes. Die Fütterungsperiode betrug 1-90 Tage. Die Änderungen in der Oberschenkelmuskulatur waren durch einen bedeutenden $(\mathrm{P} \leq 0,05)$ Rückgang (zwischen dem 50. und 90. Tag) des Wassergehaltes (von 757,20 auf 728,61 g/kg), bei gleichzeitiger Erhöhung der Trockenmasse in der Muskulatur (von 242,80 auf 271,39 g/kg) charakterisiert. In der Brustmuskulatur wurde diese Abhängigkeit nicht nachgewiesen. Der sehr niedrige Fettgehalt in der Brust(Oberschenkel-)-muskulatur der Fasanenhühner im Zeitabschnitt zwischen dem 40. und 90. Tag, der durchschnittlich 6,12 g/kg bis zu 8,33 g/kg (von 20,36 bis zu 51,37 g/kg) betrug, kann sehr positiv gewertet werden. In der Wachstumsperiode (vom 70. bis zum 90. Tag) wurde eine bedeutende Erhöhung des Fettgehaltes $(\mathrm{P} \leq 0,01)$ in der Muskulatur nachgewiesen. Die Unterschiede im Mineralstoffgehalt waren im verfolgten Zeitabschnitt in der Brustmuskulatur statistisch unbedeutend. In der Oberschenkelmuskulatur wurde ein nachweisbarer bedeutender (P < 0,01) Rückgang des Durchschnittswertes am 50. Tag $(11,75 \mathrm{~g} / \mathrm{kg})$ und in der Brustmuskulatur am 90. Tag mit 11,67 g/kg festgestellt. Die chemischen Änderungen in der Muskulatur der Fasanenhühner sind durch abnehmende Proteosynthese und eine mit dem Alter steigende Fettsynthese charakterisiert, was durch die chemischen Veränderungen in der Trockenmasse der Muskulatur belegt wird.

Schlüsselwörter: Fasan, Kupferfasan, Fütterung, Wachstum, Muskulatur, chemische Zusammensetzung der Muskel

\section{Introduction}

Game species have not been as thoroughly studied as poultry. As a result, there are very few exact studies dealing in detail with the chemical analysis of breast and thigh

*This work was part of the research plan entitled "MSM 6215712402 Veterinary aspects of food safety and quality”, supported by the Ministry of Education, Youth and Physical Training of the Czech Republic. 
muscles in pheasant. Only partial studies published by STRAKA and SIMEONOVOVÁ (2003) are available. On the basis of analysis of meat from different species of game UHEROVÁ et al. (1992) concluded that the nutritional value of game is higher than that of pork and beef. PETKOV (1988) reported average protein levels in pheasant muscles being $19.10 \%$ and $20.73 \%$ (thigh and breast muscles). The above-mentioned results are in good agreement with conclusions drawn by ZAKULA (1976), FARUGA et al. (1979), and STRAKA and SIMEONOVOVÁ (2003). From a dietetic point of view, one positive finding is that pheasant meat contains low levels of fat. Low fat content has already been reported by RICARD and PETITJEAN (1989), PETKOV (1984), and STRAKA and SIMEONOVOVÁ (2003). It is expected that fat levels in meat from farm-reared pheasants will be higher because of a enriched diet at artificial conditions. This assumption was confirmed by MIKULÍK et al. (1979) and FARUGA et al. (1979). The content of minerals in muscles is also important from a nutritional point of view. This parameter was studied in selected game species by STRMISKOVÁ and STRMISKA (1992), PETKOV (1984) and RAESAENEN et al. (1972). A study conducted by SLAMEČKA et al. (2003) is the only exact study addressing not only the chemical composition of pheasant meat but also the yield of pheasant carcass and the technological properties of pheasant meat.

\section{Materials and Methods}

The experimental monitoring was performed with 110 chickens of common pheasant supplied by a farm for the rearing of feathered game in Jinačovice u Brna. Chickens were fed on a deep bedding in the accredited experimental enclosure of the Institute for Nutrition, Zoo-technology and Zoo-hygiene of the University of Veterinary and Pharmaceutical Sciences in Brno. The enclosure was equipped with air-conditioning, light and temperature controls, and controlled zoo-hygienic and feeding technological regimens. Chickens were fed ad libitum with a feeding mixture complying with all nutritional and caloric requirements for the rearing of young broilers (Table 1). Microclimatic parameters of the experimental enclosure were as follows: average daily air temperature ranged between $31-21{ }^{\circ} \mathrm{C}$ depending on pheasants' age, average daily relative humidity was $70-75 \%$, light regimen over the whole period of feeding was 23 hours of light and 1 hour of dark. 20 randomly selected pheasant chickens aged 40, 50, 70, and 90 days were subjected to chemical analysis of muscles (breast and thigh muscles). Samples of muscles were analysed for the following parameters: water content, dry matter, protein level (nitrogen substances), fat content, and minerals (ash). The content of dry matter was determined by drying the homogenous sample of muscles at a temperature of $105^{\circ} \mathrm{C}$ till constant weight. Water content was determined as a difference between the weight of a sample before and after drying. Protein content was calculated by multiplying the content of nitrogen-containing substances (determined by using the automatic analyzer Büchi Kjeldahl) by a coefficient of 6.25. The content of fat was determined using the Soxhlet method of extraction of homogenized sample dry matter with ether. The content of minerals (ash) was determined by combustion of a homogenized sample at a temperature of $550{ }^{\circ} \mathrm{C}$. The results are expressed in g per kg of original weight and related to $100 \%$ of muscle dry matter. The results obtained were processed using mathematical and statistical methods to compare average values in the t-test implemented in the statistical programme UNISTAT. The following statistical characteristics are introduced in the 
overview of the results: $\bar{x}$ - arithmetic average, SD - standard deviation, level of significance $\mathrm{P} \leq 0.05^{*}, \mathrm{P} \leq 0.01^{* *}$, n.s. (non-significant).

Table 1

Nutritional composition of feeding mixtures used in the feeding of young pheasants (Nährstoffzusammensetzung der für die Fütterung der Fasanenhühner benutzten Futtermischungen)

\begin{tabular}{llll}
\hline Nutrients $(\mathrm{g} / \mathrm{kg})$ & $\begin{array}{l}\text { BR 1 } \\
\text { (Days 1-20) }\end{array}$ & $\begin{array}{l}\text { BR 2 } \\
\text { (Days 21-40) }\end{array}$ & $\begin{array}{l}\text { BR 3 } \\
\text { (Days 41-90) }\end{array}$ \\
\hline NS & 230.79 & 210.60 & 190.00 \\
Lysine & 13.87 & 12.05 & 11.00 \\
Methionine & 5.23 & 4.97 & 4.50 \\
Sulfur-contg. AA & 9.07 & 8.57 & 7.48 \\
Threonine & 8.57 & 7.69 & 7.00 \\
Tryptophan & 2.76 & 2.50 & 2.22 \\
Arginine & 13.55 & 12.01 & 10.31 \\
Fat & 65.94 & 72.78 & 68.22 \\
Fibre & 32.99 & 32.16 & 31.52 \\
ME (MJ) & 12.60 & 13.00 & 13.20 \\
Ash & 65.17 & 61.50 & 57.36 \\
Ca & 10.31 & 10.04 & 9.66 \\
P & 7.10 & 6.51 & 6.00 \\
Mg & 1.96 & 1.84 & 1.71 \\
Linoleic acid & 32.57 & 36.10 & 33.84 \\
Na & 1.82 & 1.81 & 1.80 \\
K & 9.51 & 8.56 & 7.52 \\
\hline
\end{tabular}

Results

A number of changes were detected in individual monitored parameters of the chemical composition of meat from young pheasants aged between 40 and 90 days. Water content and dry matter content in breast muscles varied as follows: water content in breast muscles gradually increased; however, the increase in water content in pheasants aged 40 to 50 days was not significant. Water content in muscles gradually decreased from Day 50, reaching $750.75 \mathrm{~g} / \mathrm{kg}$ (on Day 70) and $741.68 \mathrm{~g} / \mathrm{kg}$ (on Day 90). The decrease of water content in breast muscles in pheasants aged 70 and 90 days was tested statistically significant $(\mathrm{P} \leq 0.05)$. Water content in breast muscles is connected with dry matter content. During the monitoring performed from Day 40 to Day 90, a slight non-significant decrease in dry matter level was detected on Day 50. From Day 50, the content of dry matter rose up to $258.32 \mathrm{~g} / \mathrm{kg}$ (on Day 90). The increase in dry matter content in breast muscles from young pheasants between Day 70 and Day 90 was proven statistically significant $(\mathrm{P} \leq 0.05)$. Water content in thigh muscles slightly increased in young pheasants aged 40 and 50 days. Differences between average levels were tested statistically significant $(\mathrm{P} \leq 0.05)$. From Day 50 to Day 90, water content in thigh muscles gradually decreased, namely between Day 70 (735.96 g/kg) and Day 90 (728.61 g/kg) (P $\leq 0.01)$. Between Day 40 and Day 50, the average level of dry matter decreased. From Day 50, the content of dry matter in thigh muscles started to increase to $271.39 \mathrm{~g} / \mathrm{kg}$ (Day 90). The difference in dry matter level determined between Day 40 and Day 90 was tested statistically significant $(\mathrm{P} \leq 0.05)$. An overview of the average values of water content and dry matter content in both breast and thigh muscles are provided in Table 2.

Average protein levels during the monitored period ranged between $234.11 \mathrm{~g} / \mathrm{kg}$ and 244.22 in breast muscles $\mathrm{g} / \mathrm{kg}$ and between $209.82 \mathrm{~g} / \mathrm{kg}$ and $221.15 \mathrm{~g} / \mathrm{kg}$ in thigh 
muscles. Protein levels in breast muscles in pheasants aged 90 days decreased nonsignificantly to $235.04 \mathrm{~g} / \mathrm{kg}$ while in thigh muscles they dropped very significantly (P $\leq 0.01$ ) to $193.91 \mathrm{~g} / \mathrm{kg}$. The average levels of nitrogen substances estimated (protein levels) in both breast and thigh muscles are provided in Table 3.

Table 2

Variations in water content and dry matter content in breast and thigh muscles from young pheasants during growth $\left(\bar{X}\right.$ - arithmetic mean, SD - standard deviation, level of significance $\mathrm{P} \leq 0.05^{*}, \mathrm{P} \leq 0.01^{* *}$, n.s. nonsignificant) (Änderungen im Wasser- und Trockenmassegehalt in der Brust- und Oberschenkelmuskulatur der Fasanenhühner im Verlauf der Fütterung $(\bar{X}$ - arithmetisches Mittel, SD - maßgebende Abweichung, Nachweisbarkeit $\mathrm{P} \leq 0.05^{*}, \mathrm{P} \leq 0.01^{* *}$, n.s. ist nicht signifikant))

\begin{tabular}{|c|c|c|c|c|c|}
\hline & & $\begin{array}{l}\text { Breast muscles } \\
\bar{X} \pm \text { SD }\end{array}$ & significant & $\begin{array}{l}\text { Thigh muscles } \\
\bar{X} \pm \mathrm{SD}\end{array}$ & significant \\
\hline Water & Day 40 & $743.26 \pm 12.80$ & & $748.14 \pm 16.48$ & \\
\hline \multirow[t]{3}{*}{$\mathrm{g} / \mathrm{kg}$} & Day 50 & $753.13 \pm 23.09$ & n.s. & $757.20 \pm 8.39$ & $*$ \\
\hline & Day 70 & $750.75 \pm 8.90$ & n.s. & $735.96 \pm 24.85$ & $* *$ \\
\hline & Day 90 & $741.68 \pm 11.28$ & $*$ & $728.61 \pm 29.45$ & n.s. \\
\hline \multicolumn{6}{|c|}{ Dry matter } \\
\hline & Day 40 & $256.74 \pm 12.80$ & & $251.36 \pm 16.62$ & \\
\hline \multirow[t]{3}{*}{$\mathrm{g} / \mathrm{kg}$} & Day 50 & $246.87 \pm 23.10$ & n.s. & $242.80 \pm 8.39$ & n.s. \\
\hline & Day 70 & $249.25 \pm 8.90$ & n.s. & $264.04 \pm 24.85$ & $* *$ \\
\hline & Day 90 & $258.32 \pm 11.28$ & $*$ & $271.39 \pm 29.45$ & n.s. \\
\hline
\end{tabular}

Table 3

Changes in the levels of nitrogen substances in both breast and thigh muscles of young pheasants during growth ( $\bar{X}$ - arithmetic mean, SD - standard deviation, level of significance $\mathrm{P} \leq 0.05^{*}, \mathrm{P} \leq 0.01^{* *}$, n.s. non-significant) (Änderungen im Stickstoffgehalt der Brust- und Oberschenkelmuskulatur der Fasanenhühner im Verlauf der Fütterung ( $\bar{X}$-arithmetisches Mittel, SD - maßgebende Abweichung, Nachweisbarkeit $\mathrm{P} \leq 0.05^{*}, \mathrm{P} \leq 0.01^{* *}$, n.s. ist nicht signifikant))

\begin{tabular}{|c|c|c|c|c|c|}
\hline & & $\begin{array}{l}\text { Breast muscles } \\
\bar{X} \pm \text { SD }\end{array}$ & significant & $\begin{array}{l}\text { Thigh muscles } \\
\bar{X} \pm \text { SD }\end{array}$ & significant \\
\hline NS & Day 40 & $244.22 \pm 12.02$ & & $218.77 \pm 15.67$ & \\
\hline \multirow[t]{3}{*}{$\mathrm{g} / \mathrm{kg}$} & Day 50 & $234.11 \pm 21.76$ & n.s. & $209.82 \pm 8.57$ & $*$ \\
\hline & Day 70 & $238.83 \pm 7.20$ & n.s. & $221.15 \pm 18.32$ & $*$ \\
\hline & Day 90 & $235.04 \pm 12.47$ & n.s. & $193.91 \pm 17.65$ & $* *$ \\
\hline
\end{tabular}

The average levels of fat in breast muscles ranged from $6.12 \mathrm{~g} / \mathrm{kg}$ to $8.33 \mathrm{~g} / \mathrm{kg}$. Pheasants aged 90 days showed a statistically very significant increase $(\mathrm{P} \leq 0.01)$ in the average level of fat in breast muscles reaching $8.33 \mathrm{~g} / \mathrm{kg}$. The results of analyses confirm that the levels of fat in thigh muscles also increase with pheasants' age. The differences between the average levels of fat in thigh muscles until Day 90 were tested significant $(\mathrm{P} \leq 0.05)$ or very significant $(\mathrm{P} \leq 0.01)$. The average levels of fat in both breast and thigh muscles are shown in Table 4.

Young pheasants aged between 40 and 90 days showed a gradual decrease in ash levels in breast muscles (from $12.52 \mathrm{~g} / \mathrm{kg}$ to $11.67 \mathrm{~g} / \mathrm{kg}$ ). The decrease between Day 70 and Day 90 was proven statistically significant $(\mathrm{P} \leq 0.05)$. In the case of thigh muscles, a statistically significant decrease $(\mathrm{P} \leq 0.01)$ in average levels of ash was detected in pheasants aged 50 days $(11.75 \mathrm{~g} / \mathrm{kg})$. An overview of the average ash levels found in breast and thigh muscles is provided in Table 5.

The levels of individual substances were related to dry matter as this can better illustrate the quality of pheasant meat. It follows from the results that in the period from Day 40 to Day 90, the levels of protein in dry matter decreased from $951.32 \mathrm{~g} / \mathrm{kg}$ 
to $911.11 \mathrm{~g} / \mathrm{kg}$ in the case of breast muscles and from 870.42 to $740.68 \mathrm{~g} / \mathrm{kg}$ in thigh muscles. A very significant decrease $(\mathrm{P} \leq 0.01)$ in protein content was found in young pheasants aged 70 and 90 days, namely protein level dropped from $958.46 \mathrm{~g} / \mathrm{kg}$ to $911.11 \mathrm{~g} / \mathrm{kg}$ in breast muscles and from $839.61 \mathrm{~g} / \mathrm{kg}$ to $740.68 \mathrm{~g} / \mathrm{kg}$ in thigh muscles, as illustrated in Figure 1.

Table 4

Variations in fat levels in breast and thigh muscles of young pheasants during growth ( $\bar{X}$ - arithmetic mean, SD - standard deviation, level of significance $\mathrm{P} \leq 0.05^{*}, \mathrm{P} \leq 0.01^{* *}$, n.s. non-significant) (Änderungen im Fettgehalt der Brust- und Oberschenkelmuskulatur der Fasanenhühner im Verlauf der Fütterung ( $\bar{X}$ arithmetisches Mittel, SD - maßgebende Abweichung, Nachweisbarkeit $\mathrm{P} \leq 0.05^{*}, \mathrm{P} \leq 0.01^{* *}$, n.s. ist nicht signifikant))

\begin{tabular}{|c|c|c|c|c|c|}
\hline & & $\begin{array}{l}\text { Breast muscles } \\
\bar{X} \pm \text { SD }\end{array}$ & significant & $\begin{array}{l}\text { Thigh muscles } \\
\bar{X} \pm \text { SD }\end{array}$ & significant \\
\hline$\overline{\text { Fat }}$ & Day 40 & $6.41 \pm 0.96$ & & $20.36 \pm 4.40$ & \\
\hline \multirow[t]{3}{*}{$\mathrm{g} / \mathrm{kg}$} & Day 50 & $6.57 \pm 1.45$ & n.s. & $24.11 \pm 6.76$ & n.s. \\
\hline & Day 70 & $6.12 \pm 1.88$ & n.s. & $28.19 \pm 8.56$ & n.s. \\
\hline & Day 90 & $8.33 \pm 2.12$ & $* *$ & $51.37 \pm 18.18$ & $* *$ \\
\hline
\end{tabular}

\section{Table 5}

Variation in the levels of ash in both breast and thigh muscles of young pheasants during growth ( $\bar{X}$ - arithmetic mean, SD - standard deviation, level of significance $\mathrm{P} \leq 0.05^{*}, \mathrm{P} \leq 0.01^{* *}$, n.s. non-significant) (Änderungen im Mineralstoffgehalt der Brust- und Oberschenkelmuskulatur der Fasanenhühner im Verlauf der Fütterung ( $\bar{X}$ arithmetisches Mittel, SD - maßgebende Abweichung, Nachweisbarkeit $\mathrm{P} \leq 0.05^{*}, \mathrm{P} \leq 0.01^{* *}$, n.s. ist nicht signifikant))

\begin{tabular}{|c|c|c|c|c|c|}
\hline & & $\begin{array}{l}\text { Breast muscles } \\
\bar{X} \pm \text { SD }\end{array}$ & significant & $\begin{array}{l}\text { Thigh muscles } \\
\bar{X} \pm \text { SD }\end{array}$ & significant \\
\hline$\overline{\text { Ash }}$ & Day 40 & $12.52 \pm 0.91$ & & $12.47 \pm 0.76$ & \\
\hline \multirow[t]{3}{*}{$\mathrm{g} / \mathrm{kg}$} & Day 50 & $12.09 \pm 1.13$ & n.s. & $11.75 \pm 0.35$ & $* *$ \\
\hline & Day 70 & $12.08 \pm 0.62$ & n.s. & $12.70 \pm 1.21$ & $* *$ \\
\hline & Day 90 & $11.67 \pm 0.22$ & $*$ & $12.55 \pm 0.87$ & n.s. \\
\hline
\end{tabular}

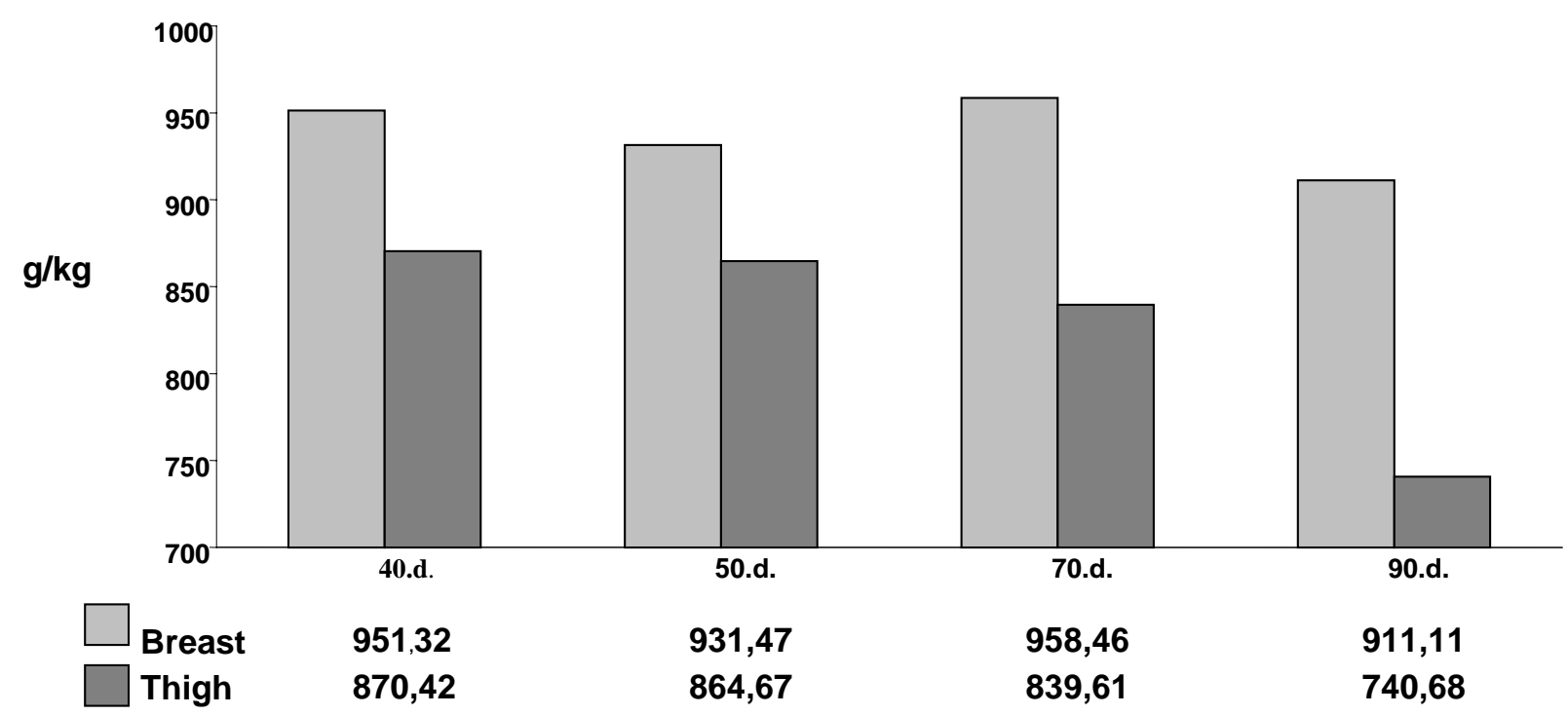

Fig. 1: Protein levels in the dry matter of muscles (Proteingehalt in der Muskeltrockenmasse) 
It was observed that fat levels during the monitored period gradually increased, namely from $24.96 \mathrm{~g} / \mathrm{kg}$ to $31.62 \mathrm{~g} / \mathrm{kg}$ in breast muscles and from $81.41 \mathrm{~g} / \mathrm{kg}$ to 186.77 $\mathrm{g} / \mathrm{kg}$ in thigh muscles, as illustrated in Figure 2. Average fat levels between Day 70 and Day 90 increased very significantly in both breast and thigh muscles, being proven very significant $(\mathrm{P} \leq 0.01)$.

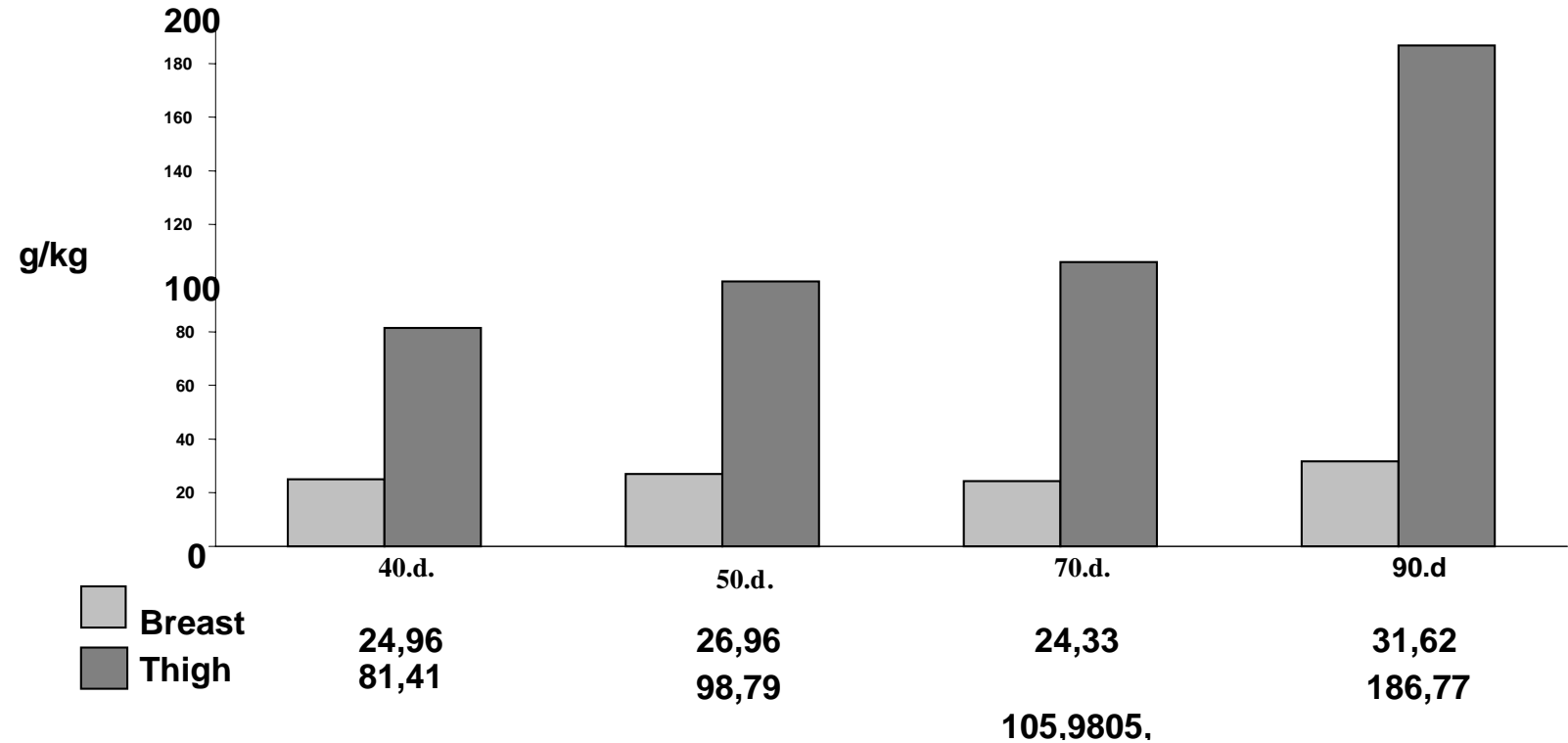

Fig. 2: Fat levels in the dry matter of muscles (Fettgehalt in der Muskeltrockenmasse)

The levels of minerals in muscle dry matter varied less significantly. However, a slight decreasing trend in the levels of minerals can also be observed in both breast (from $48.74 \mathrm{~g} / \mathrm{kg}$ to $45.24 \mathrm{~g} / \mathrm{kg}$ ) and thigh muscles (from $49.26 \mathrm{~g} / \mathrm{kg}$ to $46.74 \mathrm{~g} / \mathrm{kg}$ ), as shown in Figure 3. The average levels of minerals in breast muscles decreased very significantly $(\mathrm{P} \leq 0.01)$ between Day $70(48.47 \mathrm{~g} / \mathrm{kg})$ and Day $90(45.24 \mathrm{~g} / \mathrm{kg})$.

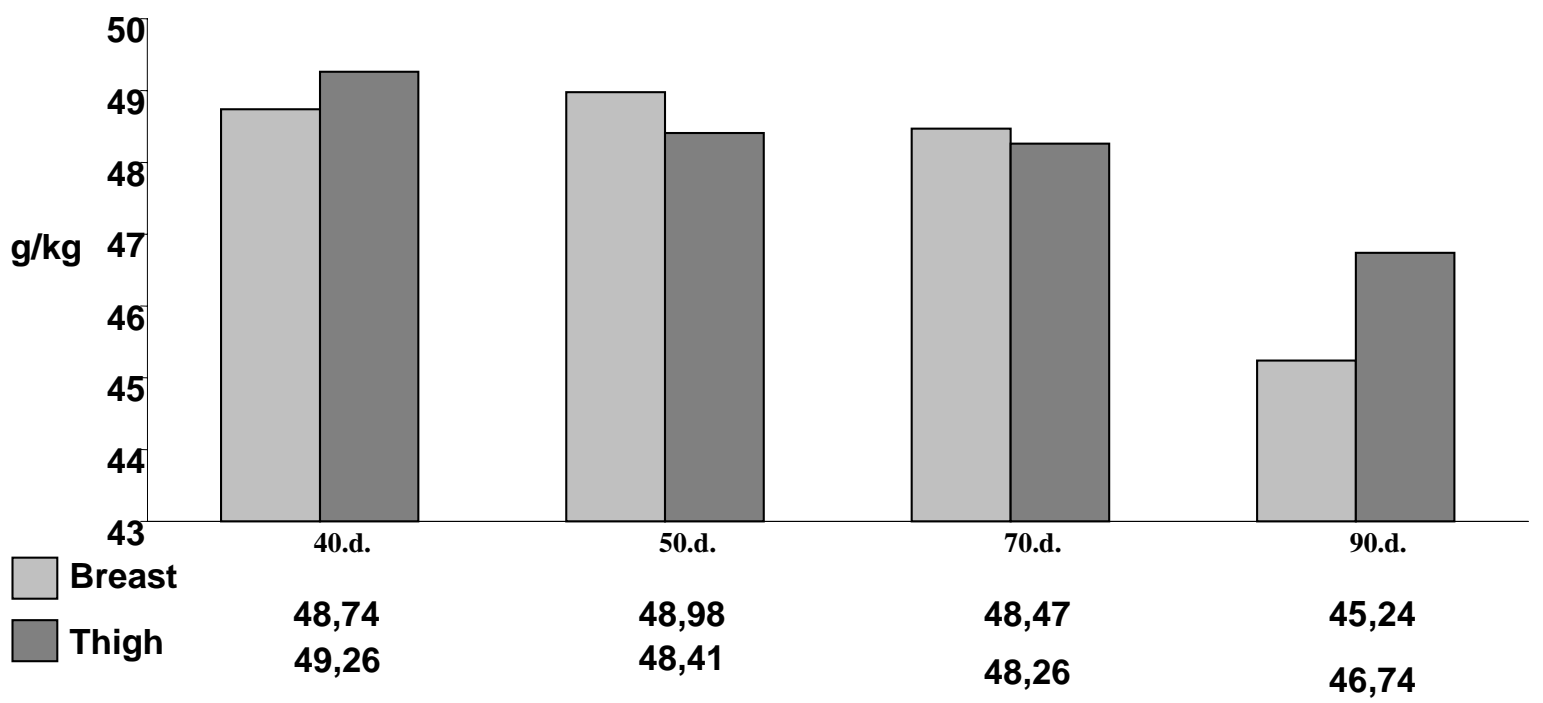

Fig. 3: Levels of minerals in the dry matter of muscles (Mineralstoffgehalt in der Muskeltrockenmasse) 


\section{Discussion}

It follows from the results of analyses that the chemical composition of pheasant meat varies significantly with the age of pheasants. From a dietetic point of view one positive finding is that pheasant meat is rich in proteins. The content of proteins determined in breast muscles from young pheasants is higher than that reported by PETKOV (1984) - 20.73 \% (207.3 g/kg) - or STRAKA and SIMEONOVOVÁ (2003) - $19.2 \mathrm{~g}$ per $100 \mathrm{~g}$ of muscles $(192 \mathrm{~g} / \mathrm{kg})$, corresponding well with the results published by FARUGA et al. (1979) who reported the content of muscle proteins in pheasant being $24.6 \%$ (240 g/kg). Higher protein levels in pheasant meat (26 g per 100 g, i.e. 260 g per kg) were reported by SLAMEČKA et al. (2003). Our results have confirmed the conclusions drawn by ZAKULA (1976) who pointed out that game is a major source of dietary protein. From a nutritional point of view one positive finding is that breast muscles from young pheasants contain low levels of fat and that the content of fat in muscles rose considerably at the end of the experimental monitoring (Day 90). This increase was proven statistically very significant $(\mathrm{P} \leq 0.01)$. This trend of increasing fat levels in muscles is in good agreement with the findings in young broilers in which a similar effect was observed particularly in females, as being attributed to ageing. A low content of fat in pheasant meat was reported by RICARD and PETITJEAN (1989) and PETKOV (1984) who found fat levels ranging between $1.01 \%$ and $3.10 \%$. These values are lower than those found in our experiment. Higher levels of fat in muscles of reared young pheasants is probably caused by intensive feeding. MIKULÍK et al. (1979) points out to the fact that the levels of fat in farmreared pheasants are higher than those in wild pheasants. The levels of ash in breast muscles are relatively unchanged. It follows from the results that no significant changes occurred in ash content during pheasants' growth, except for Day 90 when the level of ash decreased statistically significantly ( $\mathrm{P} \leq 0.05)$. Our results are in good agreement with those reported by STRMISKOVÁ and STRMISKA (1992) who published a value of $1.13 \mathrm{~g}$ of ash per $100 \mathrm{~g}$ of pheasant meat (i.e. $11.3 \mathrm{~g} / \mathrm{kg}$ ). PETKOV (1984) and RAESAENEN et al. (1972) found similar levels of ash in pheasant breast muscles, namely $1.16 \%(11.6 \mathrm{~g} / \mathrm{kg})$ and $1.20 \%$ (12.0 g/kg), respectively. Analogous conclusions can be drawn from the chemical analyses of thigh muscles. Water content and dry matter content in thigh muscles did not vary significantly during the experimental monitoring (Days 40 -90), except for Day 70 and Day 90 when water content in thigh muscles on Day 70 decreased very significantly $(\mathrm{P} \leq 0.01)$ while the level of dry matter increased. The results indicate that breast and thigh muscles from young pheasants did not substantially differ in water content and dry matter content. The evaluation of protein levels reveals variations in protein content in muscles. A dramatic decrease in protein levels particularly on Day 90 may be associated with the increasing content of fat in muscles. This finding corresponds to the conclusion published by MATUŠOVIČOVÁ (1986) who showed a statistically significant negative correlation between fat and protein levels in muscles. Protein levels found in thigh muscles in our experiment with young pheasant were in most cases significantly higher than those reported by PETKOV (1984) - $19.10 \%(191.0 \mathrm{~g} / \mathrm{kg})$ - and STRAKA and SIMEONOVOVÁ (2003) - 20.9 $\mathrm{g} / 100 \mathrm{~g}$ muscles $(209.0 \mathrm{~g} / \mathrm{kg})$.

Fat levels in thigh muscles from young pheasants gradually increase with the pheasants' age (i.e. from Day 40 to Day 90), showing a very significant increase on 
Day $90(\mathrm{P} \leq 0.01)$. This increase in fat content may arise due to increasing physical activity associated with the increasing demand for energy in muscles. It follows from a comparison of fat levels in young pheasants that were determined in this experiment that at the end of feeding (Day 90) thigh muscles contain 6.16 times more fat than breast muscles. The levels of fat determined in thigh muscles of experimentally fed young pheasants are higher than those reported by STRAKA and SIMEONOVOVÁ (2003) - $2.6 \mathrm{~g} / 100 \mathrm{~g}$ in males and $2.80 \mathrm{~g} / 100 \mathrm{~g}$ of muscles in females.

Average levels of ash in thigh muscles ranged from $11.75 \mathrm{~g} / \mathrm{kg}$ to $12.70 \mathrm{~g} / \mathrm{kg}$. It follows from the results obtained that breast and thigh muscles do not differ significantly in ash content. The levels of ash measured in our experiment are in good agreement with the content of minerals found by STRMISKOVÁ and STRMISKA (1992), PETKOV (1984), and RAESAENEN et al. (1972). Thus, we support the statement by STRMISKOVÁ and STRMISKA (1992) that pheasant meat is a significant source of minerals.

The results of analyses related to dry matter content in muscles illustrate the quality of meat and variations in the chemical composition of muscles rather more truthfully because water content may change during carcass processing, sample collection and sample analysis which may significantly affect the accuracy of the results related to the weight of fresh muscles. The results of analyses related to dry matter are documented both numerically and graphically in Figures $1-3$. The results confirm that proteosynthesis gradually decreases with the increasing pheasants' age, as assessed on the basis of a gradual decrease of levels of muscle proteins. On the other hand, the synthesis and accumulation of fat in muscle tissue increase, as documented by a gradual increase in fat content in muscles. These changes occur in young pheasants aged 70 - 90 days. Variation in the content of minerals was less significant. It follows from the graphs that breast and thigh muscles differ significantly in chemical composition. A comparison of the chemical composition of breast and thigh muscles shows that breast muscles contain significantly more proteins than thigh muscles (Fig. 1) while thigh muscles contain significantly more fat than breast muscles (Fig. 2). These differences between muscles detected in the course of the monitoring (from Day 40 to Day 90) were proven statistically significant. The differences in the content of minerals between breast and thigh muscles were not statistically confirmed (Fig. 3).

This work brings new knowledge about changes in the chemical composition of muscles in young pheasants during their growth. The results show that pheasant meat has a high nutritional value and may play an important role in human nutrition.

\section{References}

FARUGA, A.; MROZ, E.; SOBINA, I.:

Some physico-chemical and organoleptic characteristics of meat of young pheasants given rations supplemented with fat. Przemysl-Spozywczy, 29 (1979), 351 - 352

MATUŠOVIČOVÁ, E. :

Technology of Poultry Rearing. Príroda, Bratislava (1986), 393

MIKULÍK, A. ; VÁVROVÁ, M. ; NÁPRAVNÍKOVÁ, E. ; KRU゚L, J.; DOBEŠ, M.:

Chemical composition of meal of wild and domesticated pheasants. Poultry Technology, 21 (1979), 260 $-269$

PETKOV, R.:

Study of the chemical composition of pheasant meat. Veterinarno-meditsinski-Nauk, 21 (1984), 106 110 
PETKOV, R.:

Amino acid contents of meal of wild and domestic animals and birds. Khramitelna Promishlenost, 37 (1988), 14 - 16

RAESAENEN, L.; AHLSTROEM, A.; KYTOEVUORI, P.:

Nutritional values of game birds. Suomen- Kemistilehti, 45B (1972), 314 - 316

RICARD, FH.; PETITJEAN, MJ.:

Anatomical composition of the carcass of game-type pheasants and chickens of similar body weight. Nnales-de-Zootechnie, 38 (1989), 11 - 18

SLAMEČKA, J.; MERTIN, D.; HELL, P.; MOJTO, J.; JURČÍK, R.:

The yield of carcass and the quality of meat from wild pheasants and farm-reared pheasants. Folia Venatoria, 33 (2003), 135 - 143

STRMISKOVÁ, G.; STRMISKA, F.:

Contents of mineral substances in venison. Nahrung, 36 (1992), 307 - 30

STRAKA, I.; SIMEONOVOVÁ, J.:

Pheasant and its meat. Farmár, 5 (2003), 40

UHEROVÁ, R.; BUCHTOVÁ, V.; TAKACSOVÁ, M.:

Nutritional factors in game meat. Fleischwirtschaft, 72 (1992), 1155 - 1156

ZAKULA, R.:

Game as a protein source. Hrana-i-Ishrana, 17 (1976), 543 - 548

Received: 2004-12-14

Accepted: 2005-04-29

Authors' address

Doc. MVDr. VLADIMÍR VEČEREK, CSc., Prof. MVDr. Ing. PAVEL SUCHÝ, CSc.,

Doc. Ing. EVA STRAKOVÁ, Ph.D., Ing. FRANTIŠEK VITULA, Ph.D.,

MVDr. MARKÉTA MIKUNDOVÁ

University of Veterinary and Pharmaceutical Sciences Brno

Faculty of Veterinary Hygiene and Ecology

Palackého 1/3, 61242 BRNO

CZECH REPUBLIC

E-mail: vecerekv@vfu.cz 